Tersedia online: http://journal.stainkudus.ac.id/index.php/jbe

\title{
Respon Pengendara Bermotor dan Tingkat Kepatuhan Traffict Light Terhadap Keberadaan Kanopi Pohon di Persimpangan Jalan Kecamatan Mataram
}

\author{
Munawir Sazali ${ }^{1 *}$, Amirah Muhammad Umar ${ }^{1}$, Muniri ${ }^{1}$, Fahrurrozi $^{1}$ \\ ${ }^{I}$ Fakultas Tarbiyah dan Keguruan, Universitas Islam Negeri Mataram \\ *Email:sazali.bione@uinmataram.ac.id
}

\begin{abstract}
ABSTRAK
Kanopi pohon sebagai ecosystem services memberikan pelayanan berupa kenyamanan beraktifitas bagi pengendara sepeda motor saat berkendara pada siang hari. Penelitian ini bertujuan untuk menganalisis peran kanopi pohon dan respon pengendara bermotor di persimpangan jalan Kecamatan Mataram. Penelitian ini dilakukan dengan pendekatan expost pasto dengan mengkaji hubungan lebih dari satu vaiabel bebas (luasan dan kriteria kanopi) terhadap rasa nyaman dan tingkat pelanggaran traffic light di persimpangan jalan Kecamatan Mataram. Hasil penelitian ini menunjukkan bahwa kanopi pohon memberikan rasa nyaman dalam berkendara dan tertib rambu lalu lintas (traffic light). Kanopi pohon pada persimpangan Gubernuran dengan kriteria rindang, luasan kanopi mencakup seluruh badan jalan memiliki tingkat persentase kenyamanan pengendara sepeda motor sekitar $74,4 \%$ dengan jumlah pelanggaran relatif sedikit sekitar 95,33. Sedangkan unuk persimpangan jalan pasar pagutan memiliki kriteria kanopi pohon terbuka, respon kenyamanan pengendara speda motor sekitar $62,5 \%$ ratarata jumlah pelanggaran 177. Keberadaan kanopi pohon di sekitar persimpangan jalan memberikan dampak berupa kenyamanan berkendara sehingga mengurangi tingkat pelanggaran rambu lalulintas.
\end{abstract}

Kata Kunci :Kanopi pohon, Kenyamanan, Pengendara sepeda motor.

\begin{abstract}
Trees canopy as ecosystem services provided pleasantness activity for motorcycle rider broad daylight. This study was analysed of role thees canopy and drivers response at Mataram sub-district intersection. This study was carried out using the expost pasto approach with examining the relationship of more than one free variable (extensive and criteria of threes canopy) to the comfort and level of traffic light violations at the Mataram Sub-district intersection. Results of this study indicate that tree canopies provide a pleasantness of driving and orderly traffic lights. The tree canopy at Gubernuran intersection with shady criteria, this area of the canopy covering the entire road body has a level of comfort of motorbike riders around $74.4 \%$ with a relatively small number of violations about 95.33. Whereas the Pagutan market intersection has
\end{abstract}


opened tree canopy criteria, the motorbike driver's pleasantness response is about $62.5 \%$ the average number of violations 177. Therefore, existence of a tree canopy around the crossroads has the effect of driving comfort thereby reducing the level of violation of traffic signs.

Keywords: Pleasantness, Motorcycle Rider, Three Canopy.

\section{PENDAHULUAN}

Perubahan suhu udara di di perkotaandiakibatkan oleh meningkatnya jumlah kendaraan bermotor dan Ruang Terbuka Hijau (RTH) yang banyak mengalami alih fungsi (Prastyo et al., 2016).Inter-governmental Panel on Climate Change mempublikasikan gambaran pengamatan dari berbagai Negara, menyimpulkan bahwa selama tahun 1880-2012telah terjadi peningkatan suhu merata di seluruh bagian biosper sekitar $0,85(0,65-1,06)^{\circ} \mathrm{C}$. IPCC memprediksi peningkatan suhu rata-rata global akan meningkat $1,4-5,8^{\circ} \mathrm{C}\left(2,5-10,4^{\circ} \mathrm{F}\right)$ pada tahun 2100 (National Researcher Council. 2014; IPCC, 2015).

Transportasi di wilayah Kota Mataram terus mengalami peningkatanterutama kendaraan bermotor.Peningkatan jumlah kendaraan bermotor setiap tahun berpengaruh langsung terhadap peningkatan emisi gas buang kendaraan bermotor di udara (Caiazzoet al., 2013).Badan Pusat Statistik RepublikIndosesia menyatakan bahwa kenaikkan kendaraan bermotor di Indonesia tahun2005-2008 naik hingga 71\%.Oleh karena itu, perlu dilakukan pengontrolan untuk mengurangi gas buang yang berdampak terhadap peningkatan suhu lingkungan di wilayah perkotaan.

Kecamatan Mataram memiliki luas wilayah 1.076 Ha dan jumlah penduduk 7.945 Jiwa (BPS-Statistics of Mataram City 2017). Tahun 2017 kecamatan Mataram memiliki panjang jalan $64.776 \mathrm{Km}$ dengan jalan beraspal yaitu $34.853 \mathrm{Km}$ dan jalan yang diperkeras $2913 \mathrm{Km}$, sedangkan sisanya jalan tanah sepanjang 0,01 Km. Sementara jumlah kendaraan dikecamatan Mataram mengalami peningkatan dari tahun sebelumnya yaitu 11.223 unit dengan jumlah terbanyak sepeda motor yang mencapai 9.107 unit atau $81,15 \%$. Kondisi ini mendukung terjadinya peningkatan polusi udara ditambah lagi dengan perubahan fungsi lahan RTH menjadi pemukiman dan pusat pertokoan yang berakibat pada meningkatnya suhu udara di Kota Mataram. 
Pemanfaatan pohon disepanjang jalur hijau memberikan dampak positif terhadap penurunan polusi udara dari emisi kendaraan bermotor.

Currie dan Bass (2005), menjelaskan bahwa pohon dapat mereduksi polutan berupa CO di udara lebih besar dibandingkan dengan rumput, semak dan perdu. Pohon merupakan jenis tumbuhan berkayu yang mampu tumbuh besar dengan memanfaatkan hasil-hasil emisi buangan berupa karbon sebagai sumber pembentukan energi dan menghasilkan $\mathrm{O}_{2}$ melalui fotosintesis. Selain itu, pohon juga bermanfaat sebagai naungan atau kanopi dari pancaran panas cahaya matarahari sehingga kanopi pohon memberikan rasa nyaman bagi manusia atau hewan dalam melakukan aktivitas pada siang hari.

Pohon merupakan jenis tumbuhan berkayu yang mampu tumbuh besar dengan memanfaatkan hasil-hasil emisi buangan berupa karbon sebagai sumber pembentukan energidan menghasilkan $\mathrm{O}_{2}$ melalui fotosintesis (Hanafri, 2011).Chen(2016)dan menjelaskan bahwa pohon dapat mereduksi polusiyang terdapat di udara, seperti gas CO di udara $(0,06-0,57)$ lebihbesar dibandingkan dengan rumput $(0,14-0,35 \mathrm{mg})$. Selain itu, pohon juga bermanfaat sebagai naungan atau kanopi dari pancara panas cahaya matarahari sehingga kanopi pohonmemberikan rasa nyaman bagi manusia atau hewan dalam melakukan aktifitas disiang hari(Alabi dan Christian. 2013; Holtan dkk., 2014). Dalam kajian ilmu lingkungan selalu terjadi interaksi antara mahluk hidup dengan lingkungan dan mahluk hidup dengan mahluk hidup lainnya, untuk mendapatkan interaksi yang positif dengan lingkungan maka perlu dilakukan rekonstruksialur interaksi yang mengarah pelayanan ekosistem (ecosystem services)Bourguignon (2015).

Ecosystem sevices dalam penelitian ini lebih ditekankan pada pelayanan keteraturan dalam hal kondusifitas (kenyamanan) dan purifikasi karbon di udara. Pelayanan ekosistem iniberupa naungan dari pohon (threescanopy)yang ditujukan untuk manusia dalam kenyamananberaktifitas di luar ruangan sehingga secara langsung merasakan pelayanan yang diberikan oleh ekosistem. Kajian penelitian ini akan melihat peran kanopi pohon di beberapapersimpangan jalan Kota Mataram dalam berkontribusi memberikan rasa nyaman, yakniberupa kenyamanan berkendara saat berada di lampu pemberhentian pada siang hari dengan indikasi berupa para pengendara bermotor mematuhi rambu-rambu lalulintas. 


\section{METODE PENELITIAN}

\section{Lokasi Penelitian}

Penelitian ini difokuskan untuk melihat tingkat pelanggaran dari pengaruh yang ditimbulkan dari kondisi kanopi pohon di sekitar persimpangan jalan Kecamatan Mataram.Kecamatan Mataram merupakan wilayah yang terdapat di Kota Mataram yang berbatasan denganKecamatan Ampenan, Sekarbela, Sandubaya dan Lombok Barat. Pengamatan dilakukan pada 7 (tujuh) titik pengamatan yang terdapat di persimpangan jalan KecamatanMataram yang memiliki rambu-rambu lalulitas (traffic light) dengan tekhnik purposive sampling.

Titik pengamatan dipusatkan pada persimpangan jalan Kecamatan Mataram. Lokais pengamatan berada pada 7 (tujuh) titik dan diperluas sekitar 20 meter dari titik pengamatan untuk melihat kondisi lalu lintas dan luasan kanopi pada titik pengamatan yang ditentukan dengan ArcGIS 10. Pengematan dilakukan selama tiga kali pengamatan mulai dari pukul $10.00,12.00$ dan 14.00 WITA, proses pengamatan ini mengumpulkan data pengamatan berupa luasan kanopi, jumlah pelanggaran dan suhu mikro. Titik pengamatan ditentukan dengan digitasi peta Kota Mataram untuk mendapatkan titik koordnat lokasi pengamatan.

\section{Luasan Kanopi dan Tingkat Pelanggaran}

Penelitiantentang identifikasi kanopi pohon berbasis Ecologycal landscape dan Index Naturalness sebagai ecosystem seervices ini dilakukan dibeberapa titik perempatan jalan yang berada di kecamatan mataram. Pemetaan wilayah dilakukan dengan menggunakan sofwer ArcGISdan google eart yang sesui dengan tingkat kealamian wilayah (index naturalness). Angket untuk mengetahui respon pengendara motor diKecamatan Mataram.Luasan kanopi akan diukur berdasarkan luasan bayangan yang ditimbulkan oleh pohon pada titik pengamatan dengan disesuaikan pada kondisi waktu pagi,siang dan sore hari. Luasan kanopi akan menjadikan tingkat kenyamanan saat berkendara bagi pengguna sepeda motor, kenyemanan ditentukan dengan terjadinya tingkat kepatuhan terhadap rambu-rambu lalu lintas (traffic light). 


\section{Respon Pengendara Sepeda Motor}

Prosedur yang digunakan dalam penelitian ini meliputi lima tahap, yaitu penyebaran atau pembagian kuisioner kepada para pengendara bermotor, menghitung jumlah pelanggran traffict light menggunakan hand counter, mengukur suhu menggunkan thermometer digital, menganalisis data yang diperolah dan menyusun kesimpulan.

\section{Analisis Data Kenyamanan}

Menentukan tingkat korelasi antara masing-masing faktor yang berperan dalam tingkat kenyamanan pengendara sepeda motor, dilakukan uji korelasi dengan bantuan SPSS.17. Sumbangan efektif korelasi antara luasan kanopi dan suhu terhadap tingkat pelanggaran(refleksi kenyamana pengendara bermotor) dititik pengamatan persimpangan jalan KecamatanMataram.

\section{HASIL DAN PEMBAHASAN}

Kota Mataram merupakan salahsatu pusat aktifitas di Provinsi Nusa Tenggara Barat, letak wilayah Kota Mataram diapit oleh kabupaten Lombok Barat dan Selat Lombok pada $80^{\circ} 33^{\prime}-08^{\circ} 38^{\prime}$ lintang selatan dan $160^{\circ} 04^{\prime}-116^{\circ} 10^{\prime}$ bujur timur. Luas wilayah Kota Mataramadalah 61,30 km2yang terbagi dalam 6 kecamatan, salah satunya adalah KecamatanMataram. Berdasarkan hasil surve awal ditentukan ada 7 (tujuh) titik pengamatan yang dipusatkan pada persimpangan jalan yang memiliki rambu-rambu lalulintas (traffic light).

Lokasi pengamatan yang dipusatkan pada titik-titik persimpangan jalan ditentukan dengan beberapa kriteria.Kriteria kanopi yang terbentuk ditentukan berdasarkan luasan yang menaungi permukaan jalan yang berada pada titik pengamatan (Hidayat, 2010), kriteria terbuka ditentukan dengan luasan kanopi di sepanjang jalan mencapai 0-10 $\mathrm{m}^{2}$, kriteria sedang ditentukan dengan luasan kanopi di sepanjang jalan mencapai 11-20 $\mathrm{m}^{2}$ dan kriteria untuk kondisi kanopi dengan luasan mencapai $>20 \mathrm{~m}^{2}$ ditentukan sebagai kriteria berkanopi rindang.

Persimpangan yang dijadikan sebagai lokasi penelitian ini memiliki bentuk kanopi yang berbeda.Persimpangan Gubnuran memiliki bentuk kanopi yang tertutup, persimpangan Kamboja, Yaoya dan Pagutan memiliki bentuk kanopi yang terbuka sedangkan persimpangan Sriwijaya dan KFC memiliki bentuk kanopi yang 
sedang.Bentuk kanopi dan tingkat kealamian (Index naturalness)sangat mempengaruhi kenyamanan bagi pengendara sepeda motor. Dalam pemetaan ini diambil dari radius 100 meter dari titik persimpangan. Berikut ini beberapa contoh potret persimpangan jalan pada lokasi penelitian.

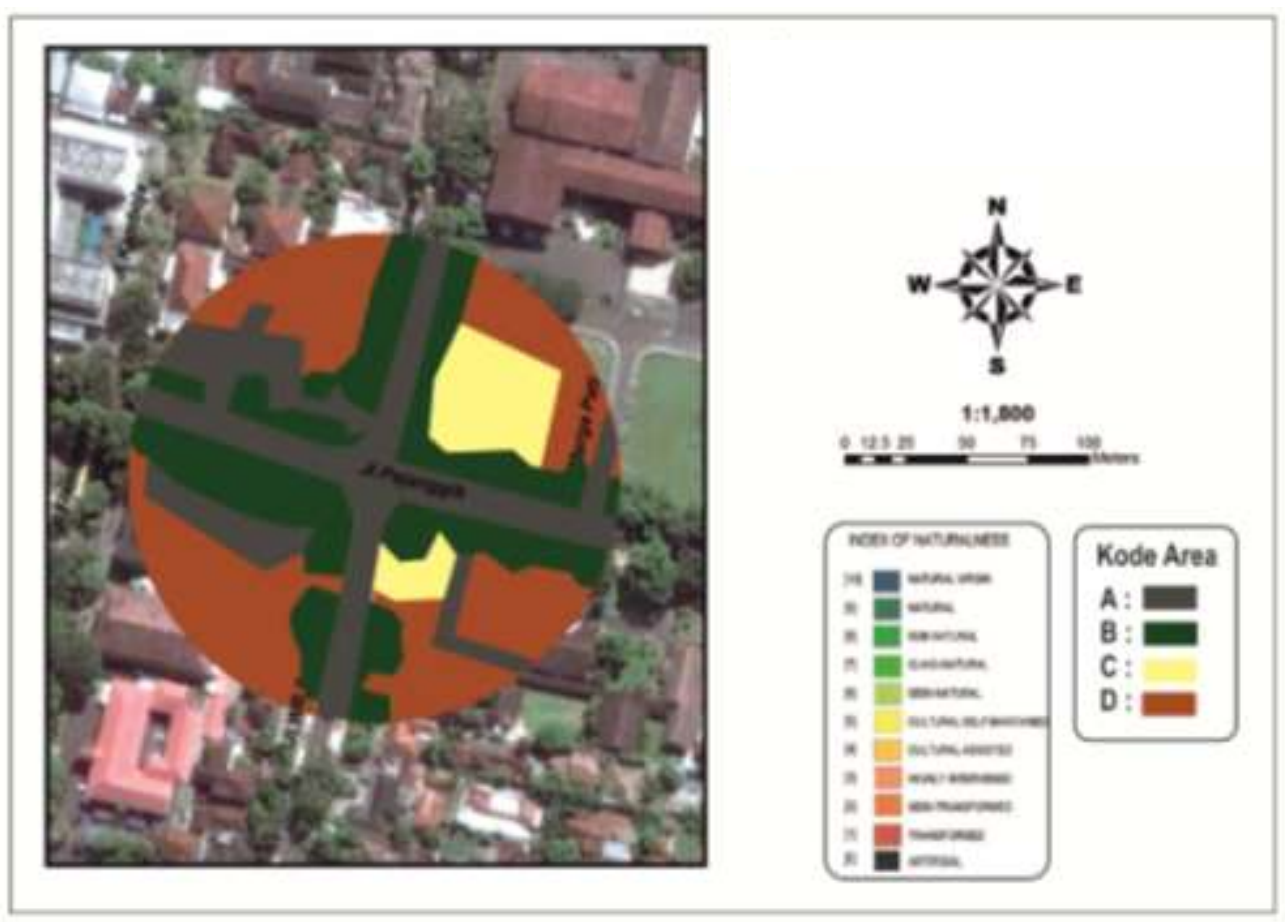

Gambar 1.Kondisi landscape persimpangan Gubernuran

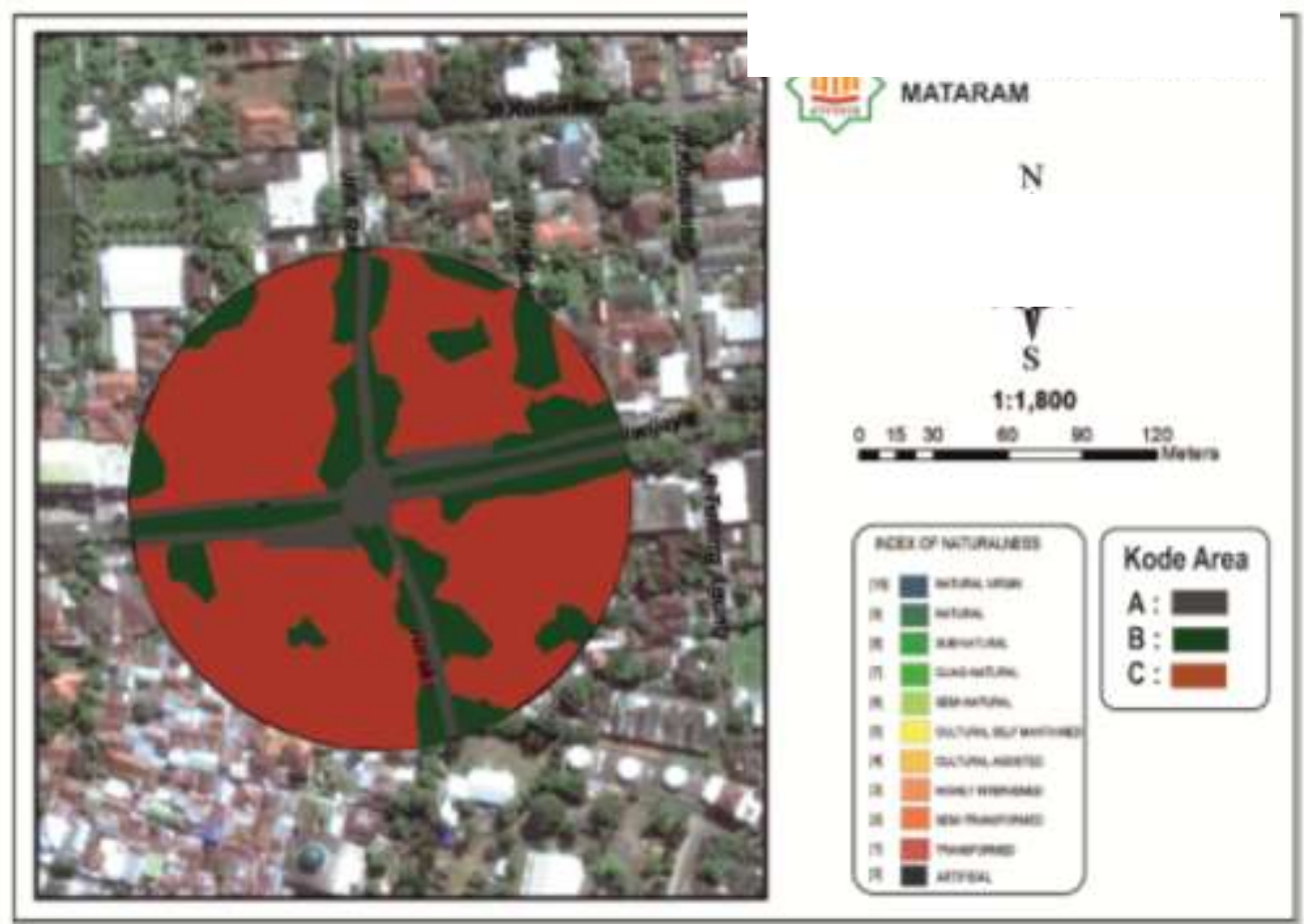


Gambar 2.Kondisi landscape persimpangan Sriwijaya

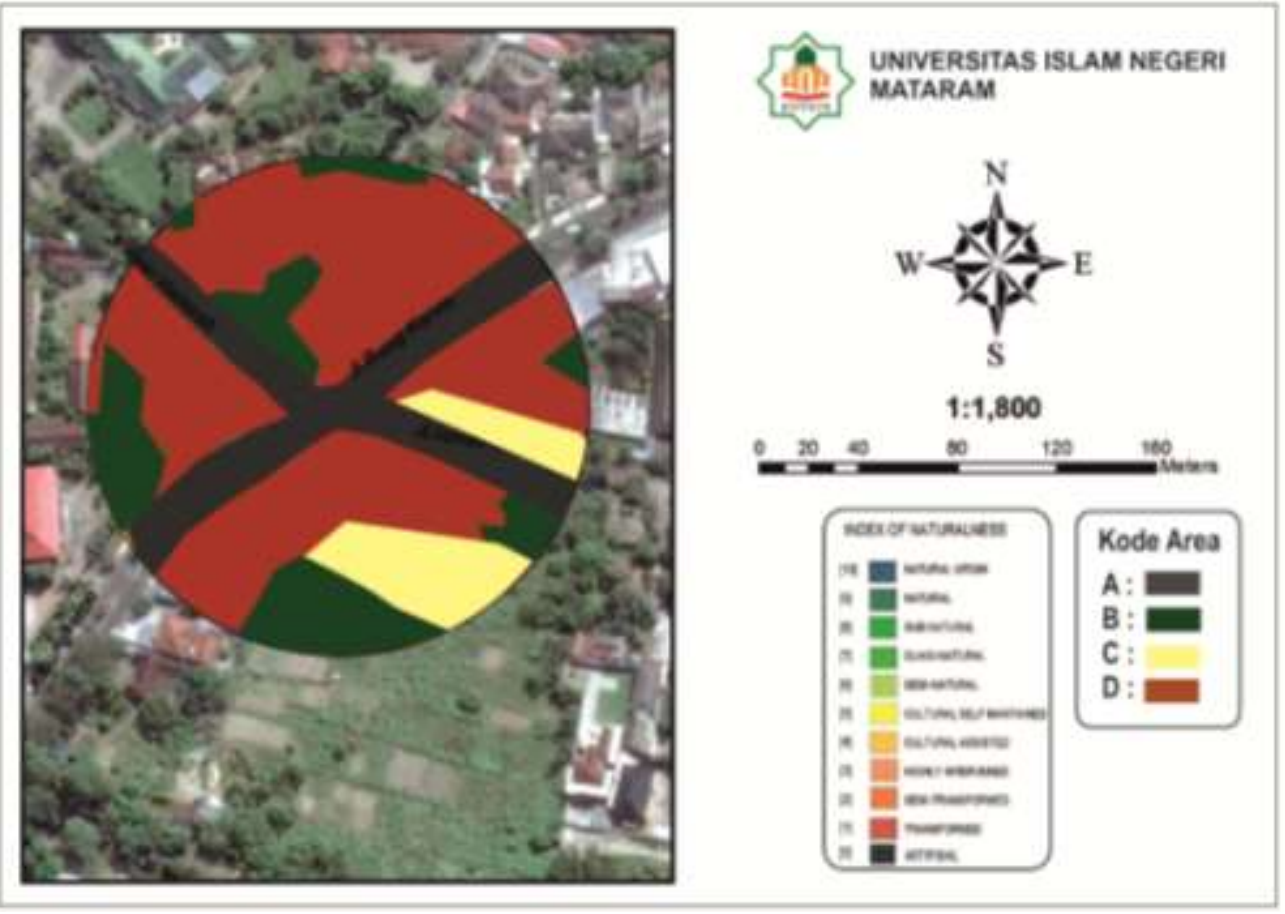

Gambar 3. Kondisi landscape persimpangan KFC

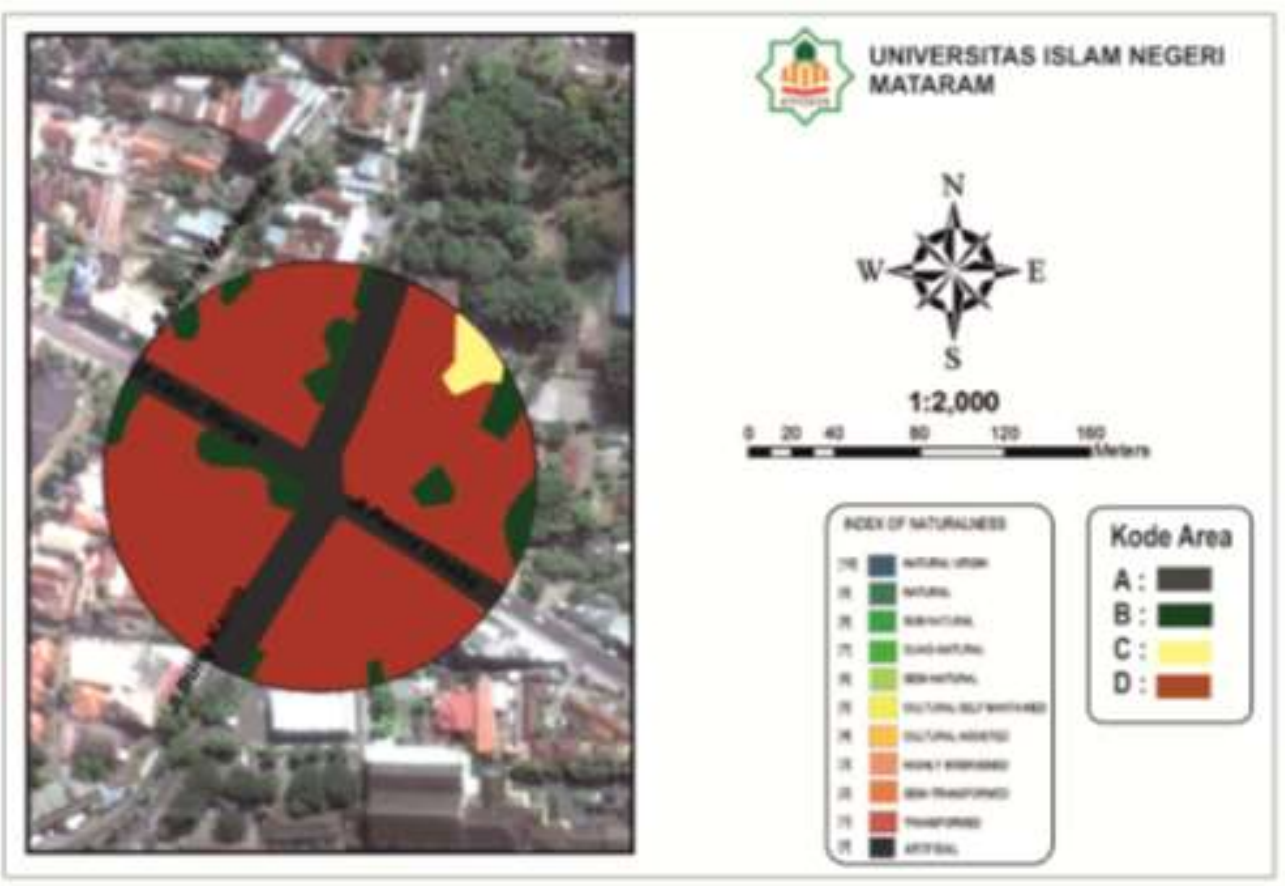

Gambar 4.Kondisi landscape persimpangan STMIK Mataram 
Lokasi pengamatan dengan kondisi kanopi pohon yang luasmemiliki respon kenyamanan yang tinggi, hal ini terbukti pada persimpangan Gubenuran dengan titik koordinat $8^{0} 582^{\prime} 868^{\prime \prime}$ LS dan $116^{0} 108^{\prime} 750^{\prime}$ ' BT memiliki kriteria kanopi pohon yang rindang, respon kenyaman pengendara speda moor sekitar $74.4 \%$. Pada persimpangan Kambodja dengan titik koordinat $8^{0} 584^{\prime} 476$ " LS dan $116^{0} 108^{\prime} 379^{\prime \prime}$ BT,memiliki kriteria kanopi pohon sedangdengan tingkat respon kenyamanan pengendra sepeda motor sekitar $67.9 \%$.Selanjutnya persimpangan Sriwijaya dengan titik koordinat $8^{0} 594$ '814" LSdan $116^{0} 107^{\prime} 935^{\prime \prime}$ BT memiliki kriteria kanopi sedang dengan tingkat kenyaman pengendara sepeda motor sekitar $70.8 \%$.

Persimpangan Golkar pada titik koordinat 80594'319'LS dan $116^{0} 112^{\prime} 807^{\prime \prime B T}$ memiliki kategori kanopi sedang dengan tingkat kenyamanan pengendara $73.7 \%$. Persimpangan STMIK pada titik koordinat $8^{0} 590$ '865'LSdan 116 $115^{\circ}$ '011'BT memiliki kategori kanopi terbuka dengan tingkat kenyamanan yang dirasakan oleh pengendara sepeda motor sekitar 67.9\%. Persimpangan Yaoya dengan titik koordinat $8^{0} 588^{\prime} 463$ " LSdan $116^{0} 117^{\prime} 482$ " BT memilikikriteria kanopi terbuka dengan tingkat kenyamanan 66.6\%. Pada Persimangan Pasar Pagutan dengan titik koordinat $8^{0} 598$ '525"LSdan $116^{0} 113$ '216"BT memiliki kriteria kanopi terbuka dengan tingkat kenyamanan pengendara sepeda motor yang dirasakan sekitar $62.5 \%$. Pada dasarnya ecosystem services menyediakan pelayanan secara langsung dan tidak langsung berupa kontribusi untuk meningkatkan kesejahteraan manusia (Sazali et al., 2017). Berdasarkan hasil peneltian ini menunjukkan bahwa kriteria kanopi rindang maka semakin tinggi tingkat kenyamaan yang dirasakan oleh pengendara sepeda motor di Kecamatan Mataram. 


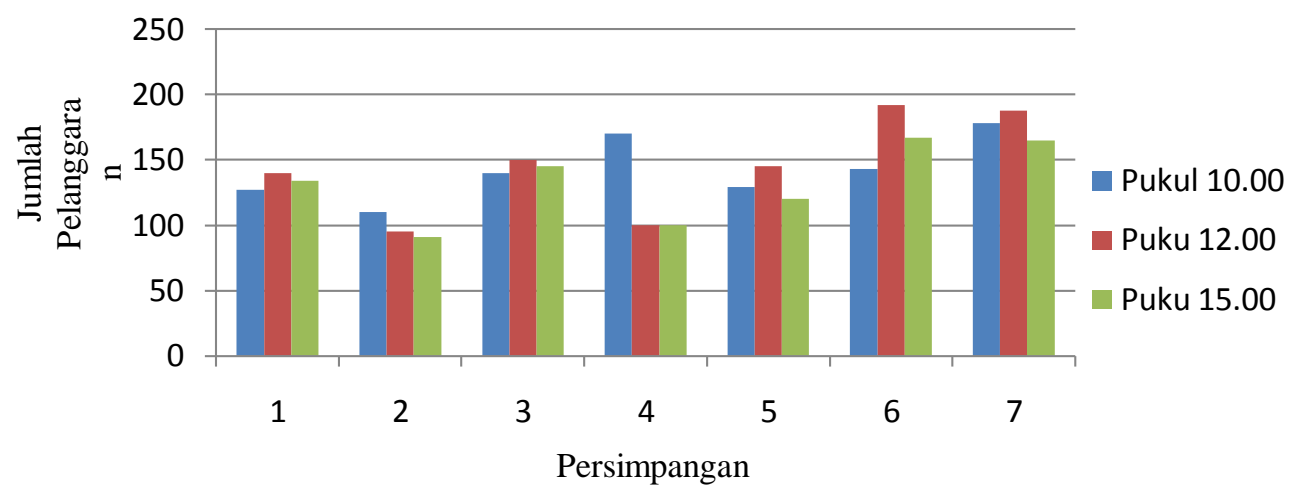

Keterangan
1. Persimpangan Kamboja
6. Persimpangan STMIK
2. Persimpangan Gubernuran
7. Persimpangan Pagutan
3. Persimpangan KFC
4. Persimpangan Sriwijaya
5. Persimpangan Yaoya

Gambar 8. Jumlah Pelanggaran Traffic Light oleh Pengendara Sepeda Motor di Kecamatan Kota Mataram

Berdasarkan luasan kanopi dan respon kenyamanan pengendara sepeda motor di Kecamatan Mataram dapat juga diamati pelanggaran yang terjadi selama proses pengamatna. Pelanggaran pengendara sepeda motor ditentukan dengan aturan ramburambu lalu lintas, yakni berhenti melewati garis pembatas (masuk ke jalur zebra cross) dan menerobos lampu merah. Setelah dilakukan pengamatan berdasarkan waktu yang sudah ditentukan pelanggaran tertinggi ada pada Persimpangan Pagutan dengan nilai 177 pelanggaran sedangkan persimpangan dengan rata-rata jumlah pelanggaran terendah ditemukan di Persimpangan Gubernuran dengan nilai 95,33 pelanggaran seperti yang ditunjukkan pada grafik di atas.

Tabel 1. Pengukuran Ecosystem Services untuk Kenyamanan Pengendara Sepeda Motor di Kecamatan Mataram, Kota Mataram

\begin{tabular}{lcccc}
\hline \multicolumn{1}{c}{ Persimpangan } & $\begin{array}{c}\text { Luas Kanopi } \\
\left(\mathrm{m}^{2}\right)\end{array}$ & $\begin{array}{c}\text { Kriteria } \\
\text { Kanopi pohon }\end{array}$ & $\begin{array}{c}\text { Respon } \\
\text { Kenyamanan }\end{array}$ & $\begin{array}{c}\text { Rerata } \\
\text { Pelanggaran }\end{array}$ \\
\hline Gubernuran & 1.411 .3 & Rindang & $74.4 \%$ & $95,33 *$ \\
Kambodja & 773,1 & Sedang & $67.9 \%$ & 133,67 \\
Sriwijaya & $1.085,8$ & Sedang & $70.8 \%$ & $108,67 *$ \\
KFC & $1.134,3$ & Sedang & $73.7 \%$ & 127,33 \\
STMIK & 194,4 & Terbuka & $67.9 \%$ & 131,33 \\
Pertokoan Yaoya & 486,5 & Terbuka & $66.6 \%$ & 123,33 \\
Pasar Pagutan & 436,5 & Terbuka & $62.5 \%$ & 177 \\
\hline
\end{tabular}


Tabel 1 menunjukkan luasan dan kriteria kanopi pohon mempengaruhi respon terhadap kenyamanan pengendara speda motor dan rerata pelanggaran terhadap traffic light. Luasan kanopi dengan pelanggaran terlihat memiliki nilai person correlation 0,838, hal ini menunjukkan terdapat korelasi secara nyata untuk masing-masing pengamatan (person correlation) antara pelanggaran dengan luasan kanopi dengan tingkat pelanggaran. Hubungan antara luasan kanopi dan kenyamanan pengendara speda motor dapat ditentukan bahwa antara kedua variabel ini terdapat hubungan (person correlation) sebesar 0,818 . Nilai negatif menunjukkan bahwa semakin luas permukaan kanopi di persimpangan jalan maka tingkat pelanggaran yang ditemukan pada setiap persimpangan jalan semakin kecil.

Peningkatan suhu udara sering dirasakan pada siang hari di daerah perkotaan dengan mobilitas penduduk yang tinggi (Prastio et al., 2016). Data stasiun klimatologi I Kota Mataram pada tahun2007 tercatat suhu udara tertinggi pada siang hari berkisar antara $23,40-31,40^{\circ} \mathrm{C}$, mengalami peningkatan pada tahun 2010 dengan suhu udara rata-rata mencapai 23,91 sampai dengan $31,94^{\circ} \mathrm{C}$ (Bapeda dan BPS Kota Mataram. 2012). Berdasarkan data BMKG Mataram rata-rata peningkatan suhu udara di kota Mataram selama 3 (tiga) tahun adalah 0,51 hingga $0,54^{\circ} \mathrm{C}$ daripeningkatan suhu secara rata-rata ini paling besar disebabkan oleh peningkatan volume kendaraan, sehingga menimbulkan efek meningkatnya ambian polusi udara di wilayah perkotaan (Hirota. 2010 \& Caiazzo, 2013). Sementara itu, pemanfaatan kendaraan bermotorsemakin dirasakan oleh masyarakat untuk kebutuhan mobilitas barang dan jasa (Oliviani danGuntur, 2014).

Mengartikan korelasi negative ini bahwa setiap peningkatan luasan kanopi maka akan semakin menurun tingkat pelanggaran di sekitar persimpangan jalan Kecamatan Mataram, hal inisangat terkait dengan faktor pendukung dari kenyamanan yang diberikan berupa peneduh dari pepohonan (Tauhid, 2008; Sitawati dan Suryanto, 2012). Peran kanopi dalam meningkatkan kenyamanan dan kepatuhan terhadap traffic light sangat didukung oleh suhu udara di sekitar badan jalan masih dalam tarap normal dan naungan dari cahaya matahari langsung (Sazali et al., 2017). Antara kenyamanan dan luasan kanopi memiliki hubungan di sebagian besar titik pengamatan, hal ini menunjukkan pengaruhluasan kanopi terhadap tingkat pelanggaran memilikikorelasi dan berupa korelasi negatif (Loughner, 2012). 


\section{SIMPULAN}

Berdasarkan hasil analisis data dan pembahasan dari penelitian ini dapat disimpulkan bahwa, terdapat korelasi antara jumlah pelanggaran dengan luasan kanopi pohon dan suhu. Masing-masing variabel memberikanpengaruh besar terhadap tingkat kenyamananpengendara pengguna sepeda motordi persimpangan jalan Kecmatan Mataram dengan melihat korelasi sumbangan relative dan efektive sebesar 51,6\% sedangkan suhudankelembaban hanya berpengaruh $11,8 \%$ dan sisanya adalah faktor luar dari pengamatan.

\section{DAFTAR PUSTAKA}

Alabi M.O dan Christian E.I. 2013.Street Tree Canopy Cover Variation Effects on Temperature inLokoja, Nigeria.Journal of Agriculture and Environmental Sciences, Vol. 2 No. 2.Hal.25-31.

Bapeda dan BPS Kota Mataram. 2012. Mataram dalam Angka Tahun 2012. Mataram. BPS KotaMataram. Hal. 4.

BourguignonD. 2015.EcosystemServices Valuing Our Natural Capital.EuropeanParliamentary Research Service.Hal. 2.

Caiazzo. F, Ashok A, Waitz I.A, Yim S.H.L, Barrett S.R.H. 2013. Air Pollution and Early Death in the United States. Part: I Quantifying the Impact Major Sector in 2005. Elsevier Atmospheric Environment Journal.Vol. 79.Hal.198-208.

Chen Y, Li Y, Li J. 2016. Investigating the Influence of Tree Coverage on Street Crime: A CaseStudy in The City of Vancouver, British Columbia, Canada. The International Archives of the Photogrammetry, Remote Sensing and Spatial Information Sciences, Volume XLI-B2.Hal.659-702.

Oliviani C dan GunturH.L.2014. Analisa Kenyamanan Kendaraan Roda Dua dengan PemodelanPengendara sebagai Multi-Sistem. Jurnal Teknik Pomits. Vol. 3, Hal.57-60.

HanafriK.S. 2011. Analisis Manfaat Kanopi Pohon dalam Mereduksi Polutan Udara Menggunakan Program City-green di Jalan Raya Padjajaran, Kota Bogor. Institut Pertanian Bogor Press.

Hidayat I.W. 2010. Kajian Fungsi Jalur Hijau Jalan Sebagai Penyangga Lingkunganpada Tol Jagorawi.Jurnal Manusia dan Lingkungan.Vol. 12.Hal.124-133.

HirotaK. 2010. Comparative studies on Vehicle Related Policies for Air Pollution Reduction in TenAsian Countries.Sustainability.Vol. 2, Hal.145-164.

HoltanT.M,Dieterlen S.L, Sullivan W.C. 2014. Social Life Under Cover: Tree Canopy and SocialCapital in Baltimore, Maryland. Journal Environment and Behavior.Vol. 6. Hal: 1-24.

Inter-governmental Panel on Climate Change (IPCC). 2015. Climate Change 2014 Synthesis Report.Geneva, Switzerland. IPCC publisher.Hal.2-3.

Loughner C.P, AllenJ.D, ZhangD.L, PickeringK.E, DickersonR.R, LandryL. 2012. Roles of Urban Tree Canopy and Buildings in Urban Heat Island Effects: 
Parameterization and Preliminary Results. Journal Applied Meteorology and Climatology. Vol.15, Hal.1775-1793.

Murdiyarso. 2003. Sepuluh Tahun Perjalanan Negosiasi Konvensi Perubahan Iklim. Jakarta.Penerbit Buku Kompas. Hal. 82.

National Researcher Council. 2014. A Report on Existing and Possible Tree Canopy in the City ofCharlotte and Mecklenburg County, NC. Washington, DC: The National Academies Press.

Prastio., Ismail M., Basith A., dan Sazali M. 2016. Studi Deskripsi Hubungan Antara Naturalness Index dan Biodivestity Index dengan Iklim Mikro pada Kelurahan Jatimulyo, Mojolangu, dan Mergosono di Kota Malang Berbasis Ecologycal Landscape. Biota Jurnal Biologi dan Pendidikan Biologi. Vol. 9 No. 1 Hal: 1831.

Sazali M., Zulfa L. I., Kusuma I., dan Pane E. 2019. Peran Kanopi Pohon Sebagai Ecosystem Sevices Berbasis Iklim Mikro Terhadap Kenyamanan Pengendara Motor di Selaparang, Kota Mataram. Seminar Nasional MIPA 2017. Mataram

Sitawati dan SuryantoA. 2012. Model Keterpaduan Pohon dalam Menentukan Indeks KenyamananRuang Terbuka Hijau (RTH). Laporan Akhir Hasil Penelitian Unggulan Perguruan Tinggi-Hibah Bersaing (Tahun Ke-1) Tahun Anggaran 2012. DIPA Universitas Brawijaya.

Tauhid. 2008. Kajian Jarak Jangkau Efek Vegetasi Pohon Terhadap Suhu Udara pada Siang Hari di Perkotaan (Studi Kasus: Kawasan Simpang Lima Kota Semarang). Semarang. Tesis Universitas Diponegoro. Hal.4-5. 